\title{
IMPLEMENTASI 7 KEBIASAAN DALAM MENGHADAPI GLOBALISASI FAKULTAS ILMU KOMPUTER UNIVERSITAS DIAN NUSWANTORO SEMARANG
}

\author{
Novi Hendriyanto \\ Fakultas Ilmu Komputer, Program Studi Teknik Informatika \\ Universitas Dian Nuswantoro Semarang \\ Email: nvhendriyanto@gmail.com
}

\begin{abstract}
ABSTRAK
Dalam perkembangan teknologi, ada pertumbuhan yang tidak kalah penting, yaitu karakter dan kebiasaan. Kebiasaan merupakan hal yang dapat membentuk karakter di masa depan dan hal ini akan sangat berpengaruh pada dihasilkannya sumber daya manusia yang handal. Pada riset ini akan diperlihatkan bahwa dengan melatih 7 kebiasaan yang sangat efektif dari Stephen R.Covey, maka akan dihasilkan sebuah bentuk manusia baru yang sangat berkualitas tinggi, dimana manusia yang dihasilkan adalah manusia yang mempunyai inovasi, kreatifitas dan dapat menghasilkan produk-produk yang berguna buat komunitasnya dan memiliki kebiasaan, karakter, dan sikap yang dapat diandalkan sebagai seorang innovator, pemimpin dan staff. Inilah yang dinamakan dengan pertumbuhan secara aksi dan bukan pertumbuhan scientific. Memang perlu diakui konsep daripada suatu pengetahuan memang penting karena merupakan dasar dari kemampuan yang harus dikuasai, tetapi perlu sejalan dengan pertumbuhan kebiasaan. Lebih jauh lagi, riset ini akan menjelaskan hubungannya dengan universitas, dosen dan mahasiswa lebih mendalam.
\end{abstract}

Kata kunci: 7 kebiasaan, mahasiswa, dosen, universitas, penerapan praktis, teknologi.

\begin{abstract}
The development of Information technology is growingvery fast, and there is something very important, namely the character and habits. Habits are things that can form the characters in the future and this will greatly affect the resulting qualified human resources. In this research will be demonstrated that by exercising 7 habits of highly effective from Stephen R.Covey, it will produce a new human form of high quality, in which human beings are produced are human beings who have the innovation, creativity and can produce useful products create community and have habits, character, and attitude can be relied on as an innovator, leader and staff. This is called a growth action and not a scientific growth. It should be recognized concept rather than knowledge is important because it is the basis of the ability to be controlled, but it needs to be in line with the growth habit. Furthermore, this research will explain his relationship with the university, faculty and students.
\end{abstract}

Keywords: 7 habits, students, faculty, university, practical applications, technology.

\section{PENDAHULUAN}

Perkembangan teknologi di abad ke 21 ini maju dengan sangat pesat tanpa ada seorangpun yang bisa mencegahnya. Dalam perkembangannya teknologi banyak sekali membantu manusia untuk menyelesaikan pekerjaannya secara efektif dan efisien sehingga hal ini, sebagai contoh pertumbuhan social network (Facebook, Twitter) bertumbuh sangat pesat sekali di Indonesia sehingga banyak orang yang memperoleh kemudahan di dalam komunikasi dan mencari informasi atau seseorang yang sudah lama tidak bertemu. Contoh lainnya seperti YouTube yang merupakan video sharing, yang memberikan kemudahan bagi para penggunanya untuk sharing.

Di sini dilihat bahwa pertumbuhan teknologi hendaknya dapat diimbangi oleh pertumbuhan karakter, karena hal ini merupakan hal yang sama-sama penting. Dalam penelitian ini akan dikemukakan bagaimana teknologi dapat mempengaruhi sikap atau karakter dan/atau bagaimana suatu sikap/karakter dapat mengubah perkembangan teknologi itu sendiri. Fokus daripada penelitian ini adalah dunia pendidikan, khususnya universitas yang merupakan basis utama dalam menghasilkan sumber daya manusia. Di sini dapat dikatakan bahwa: "Perkembangan teknologi hendaknya dibarengi oleh pertumbuhan karakter yang positif". Di dalam penelitan ini, akan mengetahui bahwa tanpa keseimbangan antara dua hal tersebut maka sumber daya manusia yang dihasikan sangat rendah dalam hal karakter, 
sedangkan karakter adalah merupakan hal dasar sebagai kunci daripada sebuah kesuksesan di masa depan.

Data yang dihadirkan dilihat dari dua sisi: kebiasaan membaca dan pengguna media sosial, data ini akan dapat memberikan informasi yang berguna sebagai dasar penelitian ini. Dasar pertama yang digunakan adalah tentang "Literacy" di Indonesia, kebiasaan membaca di Indonesia lewat media online masih sangat kurang:

Tabel 1. Data literacy online di indonesia (world culture forum, bali 2017)

\begin{tabular}{lcrr}
\hline Online News Site & Last Scanned & Daily Visitors & Daily Page views \\
\hline detik.com & 8 September 2016 & 1.125 .900 & 6.676 .788 \\
kompas.com & 3 September 2016 & 646.654 & 3.039 .274 \\
liputan6.com & 3 September 2016 & 598.784 & 1.880 .183 \\
tribunnews.com & 3 September 2016 & 461.732 & 2.622 .642 \\
merdeka.com & 3 September 2016 & 335.587 & 1.281 .943 \\
viva.co.id & 3 September 2016 & 254.429 & 859.970 \\
okezone.com & 3 September 2016 & 247.239 & 998.847 \\
tempo.co & 8 September 2016 & 199.883 & 635.630 \\
republika.co.id & 2 September 2016 & 178.784 & 561.384 \\
suara.com & 7 September 2016 & 129.426 & 336.510 \\
\hline
\end{tabular}

Dari data di atas, pada tabel 1, menurut Global Research Institution GFK dan Indonesian Digital Association (IDA), pada tahun 2015, berita dikonsumsi $96 \%$ melalui online, ini berarti bahwa hanya $4 \%$ yang di cetak, tetapi data ini belumlah cukup, data lain mengatakan bahwa kebiasaan membaca masih sangat kurang di Indonesia, kebiasaan ini jika tidak dibangun dan dibiasakan akan mengakibatkan sumber daya manusia yang dihasilkan akan sangat rendah dalam segi kualitas, datanya sesuai yang tertera pada gambar 1. Illiteracy Rate in Indonesia adalah sebagai berikut :

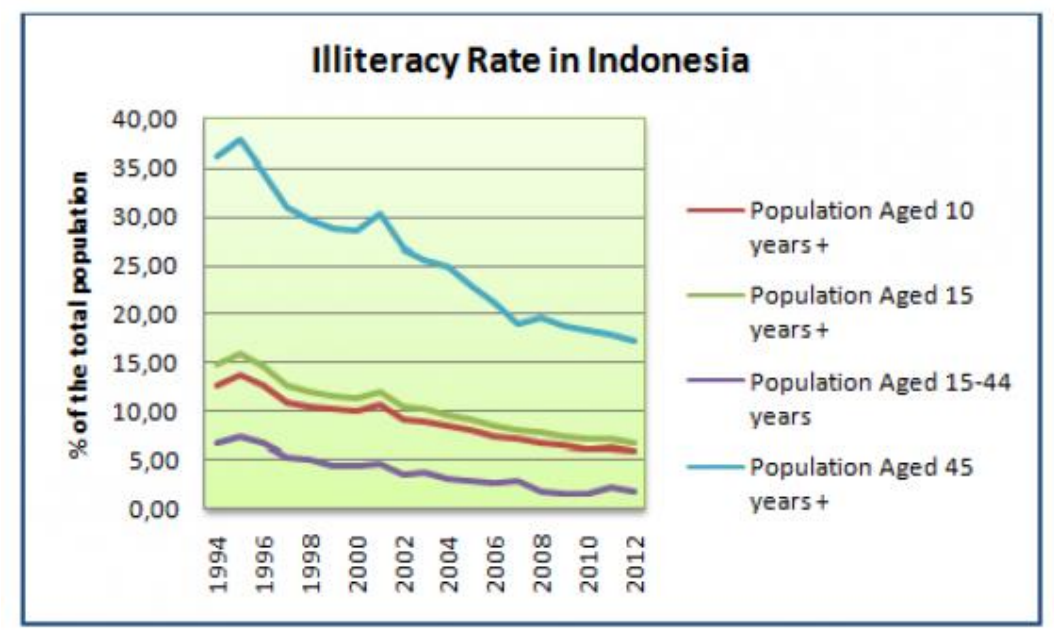

Gambar 1. Illiteracy Rate In Indonesia

Di Indonesia, dalam 20 tahun ini terdapat beberapa indikator pendidikan yang perlu diperhatikan, walaupun sudah mengalami tingkat perbaikan yang cukup, data dari 10 tahun terakhir mengatakan bahwa dari tahun 1994, sekitar $12.74 \%$ menjadi $6.02 \%$ tahun 2012 pada tingkat buta huruf, tetapi sekitar $13.79 \%$ pada tahun 1994, menjadi 5.88\% pada tahun 2012, jumlah orang di Indonesia yang pernah bersekolah. Data berikutnya adalah tentang pengguna media sosial dari snapcart, hal ini juga berpengaruh pada kebiasaan: 


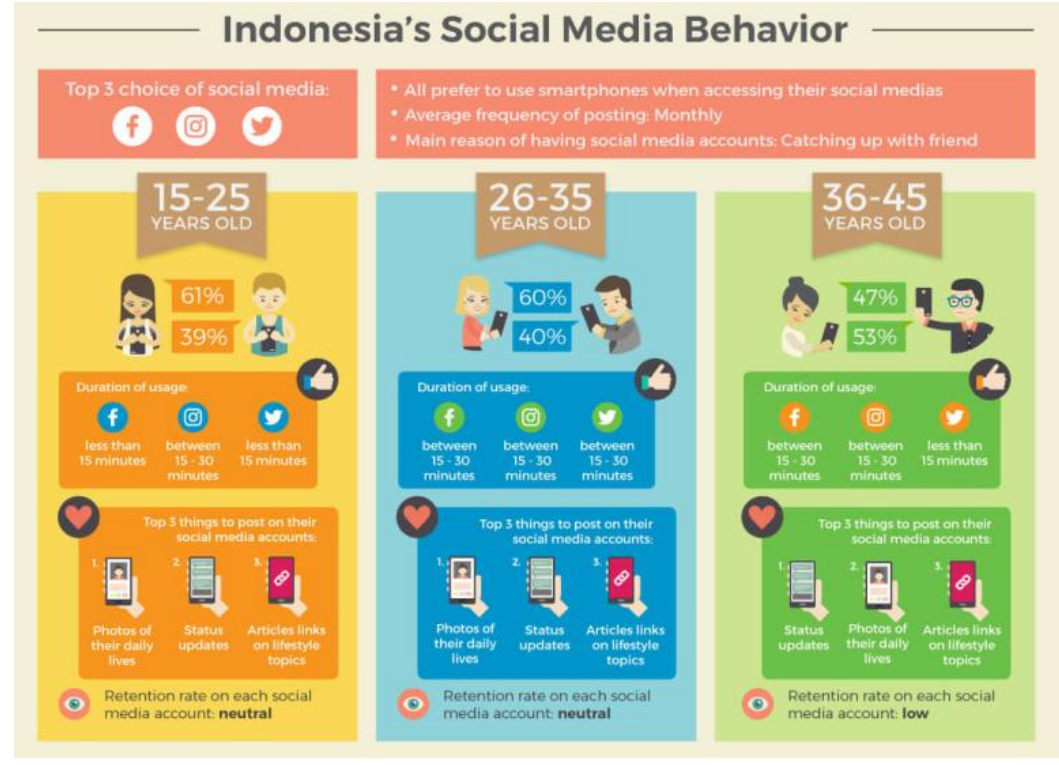

Gambar 2. Indonesia's Social Media Behaviour

Pada gambar 2, dapat dilihat bahwa pengguna sosial media di Indonesia sangat tinggi, kebiasaan dalam menggunakan smartphone untuk mengakses media sosial dalam berkomunikasi dan berinteraksi merupakan salah satu kebiasaan dan budaya di Indonesia. Disamping itu data pendukung lainnya yang bisa dikemukakan adalah sebagai berikut:

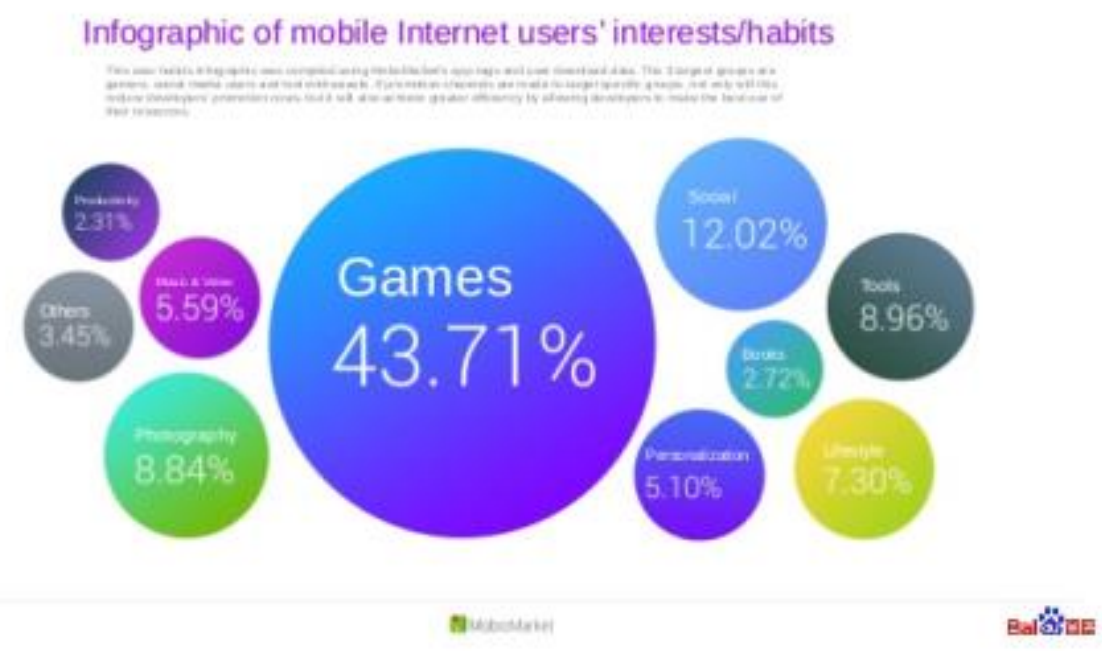

Gambar 3. Internet Habits-Indonesia

Dari gambar 3, dapat dilihat bahwa pengguna di Indonesia yang terbesar adalah games sekitar $43.71 \%$, hal ini perlu menjadi perhatian yang penting, sehingga perlu dibuatkan games berbasis pendidikan untuk dapat menyeimbangkan hal tersebut. Dari data-data yang sudah dihadirkan, pada penelitian ini akan dihasilkan sebuah kerangka untuk membantu dalam meningkatkan sumber daya manusia di tingkat Universitas, baik itu kepada dosen dan mahasiswa. Di sini perlu dibutuhkan keduabelah pihak untuk dikembangkan, sehingga dapat dikatakan "Pendidikan yang berbasis pada pengetahuan dan karakter akan dapat menghasilkan kemampuan tinggi", dengan menggunakan The $7^{\text {Th }}$ Habits Of Highly Effective People dari Stephen R.Covey, hal ini sangat membantu Pendidikan di Indonesia semakin meningkat dan siap dalam menghadapi Masyarakat Ekonomi ASEAN (MEA). Hasil dari penelitian ini akan dihasilkan kerangka E-Habits yang sangat memberikan nilai positif kepada dosen dan mahasiswa. 


\section{METODE PENELITIAN}

Dalam penerapan metode 7 kebiasaan ini yang menjadi fokus utama adalah diharapkan dosen, mahasiswa dan bahkan universitas dapat meningkatkan karakter ke arah yang positif dan lebih terfokus dalam mengembangkan jiwa kepedulian pada komunitas pada umumnya dan dapat memberikan manfaat besar serta keuntungan kepada universitas.

Pada beberapa tingkatan tertentu dan permasalahan khusus ada beberapa hal yang mungkin tidak dapat diselesaikan dan bahkan sangat rumit. Tetapi pada dasar daripada suatu permasalahan di sini adalah tidak terdapatnya kesadaran dalam perubahan di dalam diri secara mendalam. "Inside first then outside". Hal ini harus menjadi perhatian utama dalam pendidikan di Indonesia, karena gelar adalah satu hal, tetapi sungguh-sungguh dapat mempertanggung jawabkan pengetahuan adalah hal lainnya. Kebiasaan dan kebudayaan yang digabungkan dengan teknologi informasi merupakan satu tantangan besar di Indonesia, dan hal ini harus dimulai dengan melatih kebiasaan yang baik untuk mencapai hal tersebut.

Proses penelitian yang dilakukan adalah dengan mempelajari data-data yang sudah diperoleh, pengalaman yang didapat, pengamatan pada kondisi pendidikan di Indonesia dan melakukan penelitian pada beberapa jurnal yang terkait, sehingga dapat dihasilkan akurasi pada penelitian ini, kerangka penelitiannya adalah sebagai berikut:

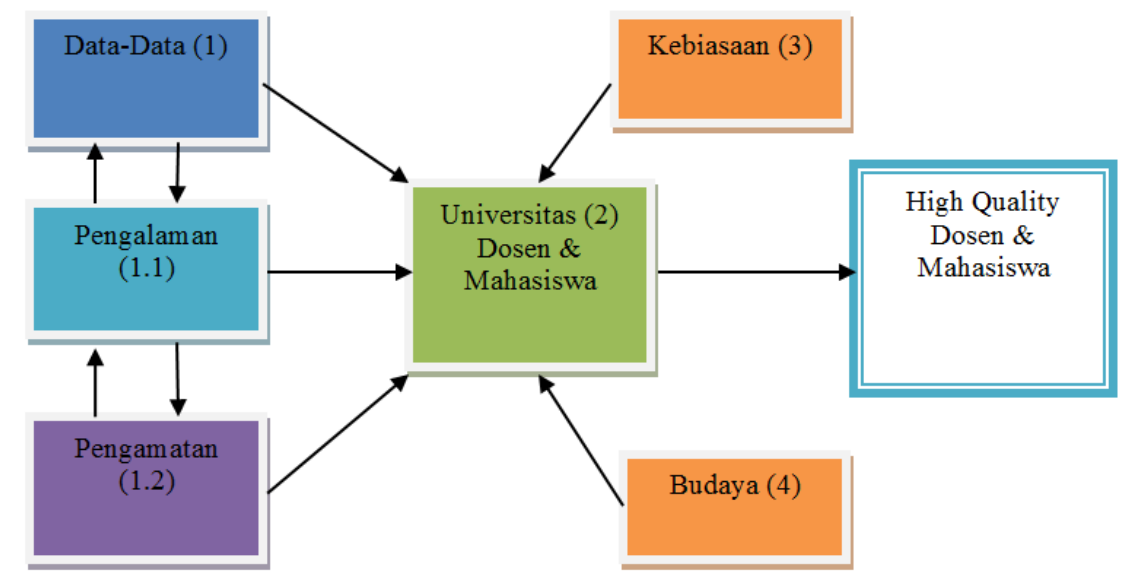

\section{Gambar 4. Kerangka Proses Penelitian Dan Pembuatan Kerangka E-Habits}

Kerangka proses harus dapat dibentuk terlebih dahulu, sebelum menerapkan konsep 7 kebiasaan ini, pada gambar 4, proses pertama dilakukan pengumpulan data-data yang telah dihadirkan di awal, dan kemudian disatukan dengan pengalaman dan pengamatan yang akurat, melalui riset melalui internet dan melihat kondisi beberapa tempat, dari sini dapat disimpulkan bahwa kebiasaan dan budaya juga memiliki pengaruh yang besar terhadap Universitas, oleh sebab itu proses di dalamnya sangatlah penting untuk diperhatikan, terakhir dihasilkan sumber daya manusia yang memiliki kualitas tinggi. Lebih jauh lagi, penyatuan antara penggunaan teknologi informasi human resource dan pengendalian kualitas sangat perlu dikembangkan agar dapat diperoleh sebuah sistem human resource yang dapat meningkatkan kompetensi sesuai dengan bakat yang dimiliki oleh orang tersebut, dengan cara mengajarkan bagaimana secara konsisten untuk memelihara, menjalankan dan merenungkan kebiasaan-kebiasaan yang baik, ini kami namakan Kecerdasan Hidup.

\section{HASIL DAN PEMBAHASAN}

Pada bagian hasil dan pembahasan ini, akan dibahas bagaimana cara menerapkan konsep 7 kebiasaan ke dalam tingkatan yang lebih tinggi, tidak hanya berbasis kepada manusia tetapi bagaimana teknologi informasi akan dapat memberikan pengaruh kepada perkembangan pengetahuan, karakter, sikap dan kebiasaan-kebiasaan yang akan dimiliki oleh manusia tersebut. di satu sisi memang pengembangan pengetahuan sangat dibutuhkan untuk meningkatkan kompetensi, tetapi jika kita melupakan sisi psikologi manusia, maka hal itu akan sangat tidak baik, kita ingin mendapatkan dan menghasilkan sumber daya manusia yang memiliki kecerdasan tinggi tetapi memiliki karakter yang baik dan benar, tidak hanya satu sisi yang terlihat, yaitu kecerdasannya tetapi karakter dan sikapnya tidak baik, dan satu sisi lain terlihat baik tetapi tidak memiliki pengetahuan. Oleh sebab itu, kedua hal ini harus dapat dijaga keseimbangannya, bukan hanya jatuh pada satu sisi dan mengorbankan sisi lainnya. Oleh sebab itu, 
the 7 habits ini merupakan metode yang tepat untuk dapat diterapkan ke dalamnya, yang dimana akan dihasilkan human technology yang sungguh-sungguh dapat memberikan kontribusi positif kepada masyarakat dan kemajuan teknologi informasi di Indonesia.

\subsection{The 7 Habits By Stephen R.Covey}

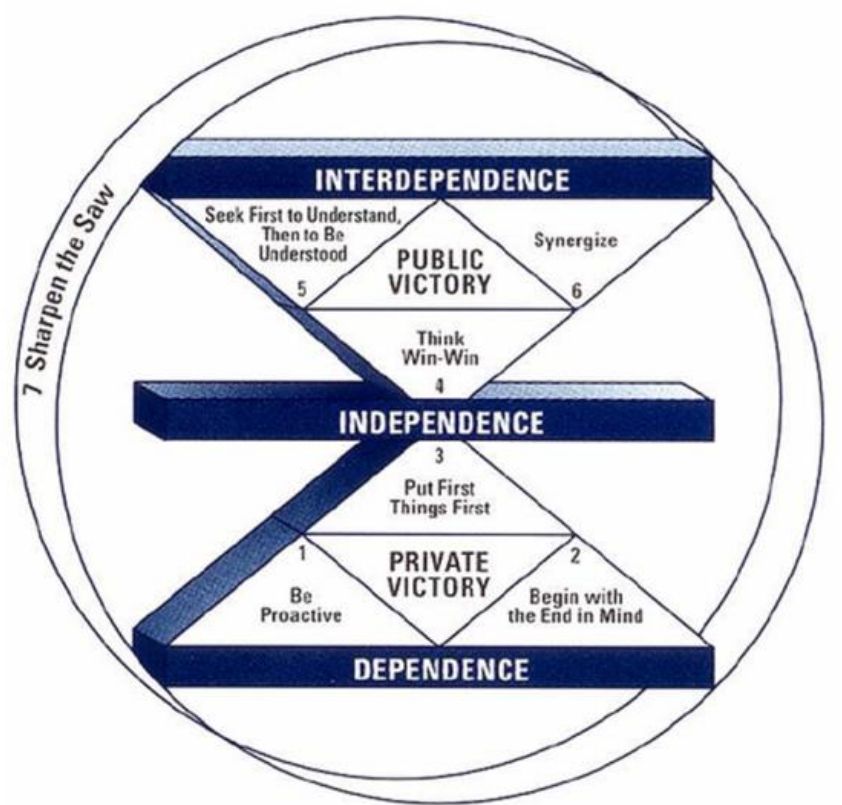

Gambar 5. The $7^{\text {th }}$ Habits Of Higly Effective People (Stephen R. Covey).

Sebagaimana sudah dipahami bahwa dibutuhkan peningkatkan sumber daya manusia dengan tidak hanya memperhatikan pada satu sisi saja tetapi mengorbankan sisi lainnya, 7 kebiasaan merupakan tahapan dalam meningkatkan kebiasaan yang baik, pada gambar 5 konsep dari Stephen R.Covey , yaitu 7 Kebiasaan manusia yang sangat efektif ini sudah sangat terkenal di seluruh dunia. Ini merupakan konsep yang sangat luar biasa jika sungguh-sungguh diterapkan ke dalam sistem pendidikan karena akan dapat menghasilkan sumber daya yang luar biasa dan boleh dikatakan berkualitas tinggi baik dalam hal pengetahuan maupun karakter. Di dalam riset ini penjelasannya singkatnya adalah sebagai berikut: [10]

Kebiasaan 1: Proaktif - Manusia harus bertanggung jawab kepada dirinya sendiri dan mempunyai nilai tanggung jawab tinggi dalam hidup ini.

Kebiasaan 2: Merujuk pada tujuan akhir, atau mulailah dengan mengingat-ingat tujuan - Seseorang harus mampu mendefinisikan misi dan sasaran hidupnya dengan benar.

Kebiasaan 3: Dahulukan yang utama - Seseorang harus mampu menyusun prioritas-prioritas terpenting dalam hidupnya sehingga arah hidupnya dapat lebih terfocus dan melakukan hal-hal yang memang benar-benar penting.

Kebiasaan 4: Berpikir Menang-Menang - Bersikap diplomatis dalam menyelesaikan sebuah permasalasahan dengan benar, jujur, etis dan ber integritas.

Kebiasaan 5: Berusaha memahami terlebih dahulu, baru dipahami - Seseorang harus menjadi pendengar yang baik terlebih dahulu dalam menyelesaikan suatu permasalahan.

Kebiasaan 6: Wujudkan Sinergi - Seseorang harus mampu bekerja sama dengan baik dan benar dalam mencapai hasil yang positif.

Kebiasaan 7: Asahlah Gergajimu - Seseorang harus mempunyai sifat mau diajar dan bertumbuh baik dalam pengetahuan maupun karakter demi kepentingan komunitas dan dirinya.

Dari sini kita dapat memahami bahwa 7 kebiasaan ini akan sangat mempengaruhi hidup seseorang dan terutama perubahan dan masa depan yang sangat luar biasa akan didapatkan pada saat dengan konsisten melakukan 7 kebiasaan ini. [1];[7];[17];[18];[19]. 


\subsubsection{Penerapan Ke Dalam Dosen}

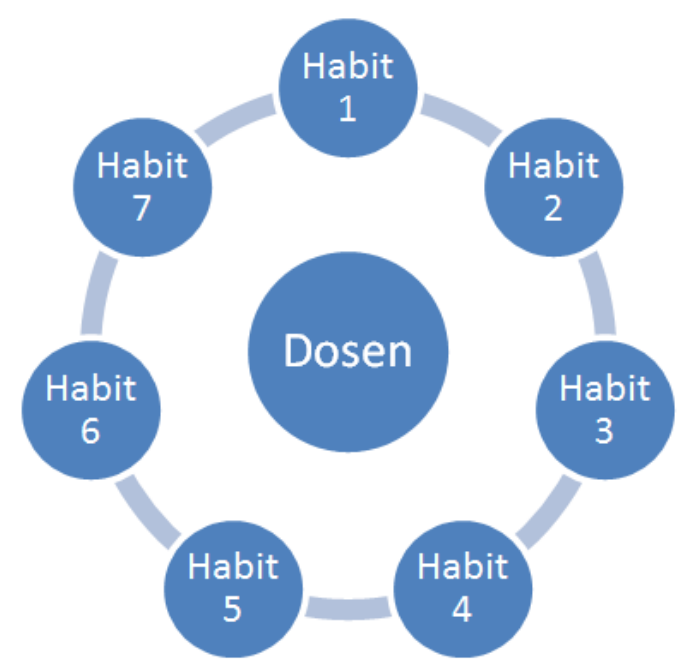

Gambar 6. Dosen dan 7 Kebiasaan Yang Efektif

Pada gambar 6 ini dilihat bahwa dosen dikelilingi oleh konsep 7 kebiasaan yang efektif. Apakah maksud dari hal ini?. Hal ini dimaksudkan untuk mencapai hasil yang luar biasa dalam proses belajar mengajar dan mendapatkan respek dari para mahasiswa, dosen hendaknya dapat mengubah dirinya terlebih dahulu sebelum mengubah diri para mahasiswanya. Penerapannya adalah sebagai berikut:

Kebiasaan-1 Dosen proaktif : Dosen yang proaktif mempunyai sifat dalam mengembangkan dirinya sendiri seperti pengetahuan yang perlu dipelajari guna memberikan yang terbaik kepada mahasiswanya. Hal ini juga dapat meliputi menguasasi teknologi-teknologi baru yang dapat berguna untuk kemajuan dirinya, para mahasiswanya dan memberikan keuntungan serta manfaat kepada universitas dan komunitas masyarakat. Lebih jauh lagi, dalam mengerjakan dan menyelesaikan tugas-tugas yang diberikan oleh Jurusan atau Departemen dilaksanakan dengan sangat bertanggung jawab. Dengan melatih dan menerapkan kebiasaan 1 ini, maka akan dapat dihasilkan dosen yang berkualitas tinggi, yang mana tidak hanya mengajar apa yang sudah ada tetapi lebih daripada apa yang memang perlu diberikan kepada mahasiswa dan universitas serta komunitas masyarakat. [20]

Kebiasaan-2 Dosen yang merujuk pada tujuan akhir atau mulailah dengan mengingat-ingat tujuan akhirnya. Dosen harus mempunyai misi dan sasaran dalam hidupnya ini hal yang utama terlebih dahulu karena jika dosen tidak memiliki sasaran dan misi dalam hidupnya bagaimana mungkin dapat mengajarkan hal yang benar kepada para mahasiswanya. Hal utama yang perlu dipahami adalah jika profesi dosen hanya merupakan sekedar profesi tetapi tidak dapat memahami jiwa yang sesungguhnya dan esensi dari seorang pendidik maka hal ini akan sangat membahayakan. Mengapa ? Karena dosen akan hanya memberikan apa yang sudah diketahuinya dahulu tetapi di dalam dirinya tidak ada pengembangan diri oleh karena tidak mempunyai sasaran dan misi dalam hidupnya.[2];[3] Sasaran dan misinya sudah jelas yaitu sebagai dosen, seorang pendidik yang harus memberikan contoh baik dalam tingkah laku, karakter yang etis dan bermoral serta mampu mengembangkan dirinya, menghasilkan prestasi dan menghasilkan inovasi dalam ilmu pengetahuan.

Kebiasaan-3 Dosen yang mempunyai prinsip dahulukan yang utama. Dosen di sini harus mampu menyusun prioritasnya dengan benar. Maksudnya adalah prioritas-prioritas yang disusun haruslah berhubungan dengan kemajuan teknologi dan harus didampingi dengan pengembangan karakter. Sebagai contoh sederhana, dosen berlama-lama menggunakan Facebook dan Twitter atau media sosial lainnya tetapi tidak untuk melakukan riset, hanya untuk kesenangan, hal-hal itu semua tidak dibenarkan jika tidak menghasilkan sesuatu yang positif. Penggunaan teknologi untuk membantu efektifitas dan efisiensi kerja memang sangat diperlukan tetapi jika hanya untuk kesenangan yang tidak menghasilkan apa-apa maka hal ini akan membuang waktu dan tidak dihasilkannya kualitas yang tinggi. Bekerja harus dapat menempatkan prioritas demi kepentingan mahasiswa, pengembangan diri, universitas dan komunitas masyarakat sehingga hal ini akan menghasilkan sumber daya dosen yang berkualitas tinggi. [4];[5];[6]

Kebiasaan-4 Dosen yang berpikir menang-menang. Dosen di sini tidak bersikap otoriter yang keras. Maksudnya adalah memang diperlukan disiplin di dalam proses belajar mengajar tetapi tanpa mempunyai empati hal itu tidak akan berhasil dalam proses belajar mengajar dan meningkatkan kualitas. Dosen harus mampu menggabungkan sikap disiplin yang keras dengan kelemah lembutan, bukan jatuh pada satu sisi saja, dimana dosen - mahasiswa - universitas mampu menghasilkan solusi daripada suatu permasalahan 
bukan menghasilkan masalah lainnya. Masalah adalah merupakan sesuatu yang memang perlu kita hadapi, tetapi solusi jauh lebih penting dari permasalahan itu sendiri dan hendaknya kita belajar jangan menyelesaikan suatu permasalahan dengan permasalahan lainnya.

Kebiasaan-5 Dosen yang mempunyai karakter memahami terlebih dahulu, baru dipahami. Dosen harus mampu melatih kebiasaan dalam mendengar permasalahan dari para mahasiswanya. Masalah pada setiap mahasiswa tentunya akan sangat bervariasi, dan apakah ini akan menyita waktu dosen ? jawabannya adalah tidak. Dengan melakukan pendekatan yang baik dan kesabaran dalam membimbing maka dosen pun akan banyak belajar dalam mengembangkan dirinya untuk mengajar dengan hati bukan hanya dengan kepala saja.[8];[9]

Kebiasaan-6 Dosen yang mampu mewujudkan sinergi. Di sini dosen harus mampu bekerja sama dengan mahasiswa dan pihak universitas agar dapat dihasilkan hal-hal yang positif dan luar biasa baik dalam menghasilkan teknologi maupun pengembangan diri yang baik. Tetapi perlu diingat dengan baik bahwa mewujudkan sinergi hendaknya memperhatikan faktor etika karena ini akan sangat berpengaruh kepada masa depan dosen itu sendiri, mahasiswa dan universitas.

Kebiasaan-7 Dosen yang mengasah gergajinya terus. Dosen harus mampu terus mengasah kemampuannya dengan fokus mata pengembangan mata kuliah yang diajarkannya sehingga ini akan menghasilkan inovasi-inovasi yang berguna bagi para mahasiswanya, universitas dan komunitas masyarat pada umumnya. [30];[31];[32]

\subsubsection{Penerapan Ke Dalam Mahasiswa}

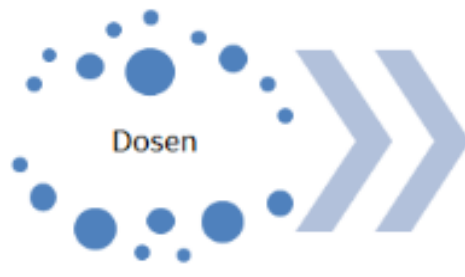

7 Habists

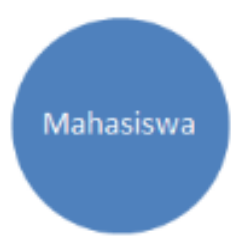

7 Habits

Gambar 7. Dosen - Mahasiswa - 7 Habits

Setelah memahami proses 7 kebiasaan yang harus dilakukan oleh dosen, maka berikutnya hal yang tidak kalah penting adalah penerapan 7 kebiasaan ini kepada mahasiswa. Perlu dipahami bahwa perkembangan teknologi memberikan banyak kemudahan kepada para mahasiswa untuk mendapatkan informasi guna menyelesaikan kuliahnya tetapi ada satu permasalahan yang perlu bahkan sangat perlu dan sangat penting diperhatikan adalah masalah penggunaan teknologi menghasilkan kebiasaan yang tidak baik dan penjiplakan hasil karya orang lain yang berujung kepada plagiarisme. Dosen harus mampu untuk membimbing para mahasiswanya ke arah yang benar dengan menerapkan 7 kebiasaan yang telah dilatihnya secara konsisten.

Kebiasaan-1 Mahasiswa yang proaktif. Mahasiswa harus dilatih dan dibimbing untuk mempunyai karakter yang bertanggung jawab dalam menyelesaikan tugas-tugasnya dengan baik. Karena suatu nilai tanggung jawab adalah mempunyai suatu nilai hakiki yang tidak dapat digantikan oleh apa pun untuk masa depannya. Sebagai contoh, dosen dapat memberikan bimbingan, pengarahan dan contoh yang baik dalam penggunaan sumber-sumber aplikasi, software atau lainnya untuk mengembangkan kemampuan mahasiswa dalam mendapatkan informasi dan memberikan informasi yang baik. Karena, perlu dipahami "demam ingin menjadi artis" telah melanda kalangan muda, dimana dengan mudahnya mengekpresikan hal-hal yang tidak penting di dunia maya dan ini akan berakibat tidak baik kepada mahasiswa itu sendiri. Beritahukan, berikan contoh hal-hal positif apa saja yang akan diperoleh oleh mahasiswa di masa depan dan hal-hal negatif apa saja yang akan didapatkannya jika menggunakan Facebook atau teknologi lainnya secara tidak bertanggung jawab dan efek samping apa yang akan diperolehnya. Mungkin ada statement yang mengatakan bahwa mahasiswa sudah dewasa dan seharusnya mereka mengetahuinya itu sendiri. Di sini terdapat pembelajaran bahwa tidak semua mahasiswa mengetahuinya dan banyak hal-hal yang memang perlu mereka ketahui untuk masa depannya dan ini merupakan tanggung jawab dari dosen dan mahasiswa bukan salah satunya.

Kebiasaan-2 Mahasiswa yang mempunyai sasaran hidup dan tujuan yang jelas. Banyak dari mahasiswa di zaman sekarang ini tidak mempunyai sasaran dan tujuan hidup yang jelas sehingga pada saat kuliah mereka bermalas-malasan dan seakan-akan menjalani perkuliahan hanya sebagai rutinitas tetapi sesungguhnya tidak tahu apa yang ingin dicapainya dalam hidup dan masa depannya. Dalam hal 
ini, dosen harus mampu untuk membimbing mahasiswa secara sabar dan empati untuk memahami permasalahan yang ada dan mengarahkan para mahasiswanya agar dapat mempunyai sasaran yang jelas dan misi yang jelas. Apakah yang dijalani oleh para mahasiswa baik itu di jurusan sistem informasi, informatika atau manajemen ataupun jurusan lainnya sudah sesuai dengan panggilan hidupnya yang sebenarnya atau para mahasiswa hanya kuliah untuk mendapatkan gelar tetapi pada akhirnya gelar hanya sekedar gelar bukan untuk memberikan manfaat bagi kepentingan komunitas. Di sinilah tantangan yang cukup berat karena diperlukan kesabaran tinggi untuk memahami satu persatu para mahasiswa dan permasalahannya.

Kebiasaan-3 Mahasiswa yang mempunyai karakter first things first. Mahasiswa di sini harus dapat menetapkan prioritas yang terpenting dalam hidupnya dan kuliahnya. Kebanyakan dari mahasiswa menghabiskan waktu berjam-jam untuk melakukan hal-hal yang tidak perlu untuk dilakukan. Sebagai contoh: Menghabiskan waktu untuk terus menerus bermain Facebook dan lainnya sehingga hal ini menghasilkan mahasiswa yang mempunyai karakter "Beralasan" dan tidak mempunyai dasar yang kuat dalam mengembangkan ilmu pengetahuan dan karakternya. Dosen hendaknya mampu untuk menasehati para mahasiswa serta memberikan contoh apa akibat dari tidak dapat menetapkan prioritas dan hal-hal positif apa yang akan di dapat di masa depan jika mahasiswa mampu untuk menetapkan prioritas atau hal-hal yang benar-benar penting dalam hidupnya dan kuliahnya.[11]

Kebiasaan-4 Mahasiswa yang berpikir menang-menang. Pada tahapan ini adalah merupakan tahapan yang tidak mudah karena karakter setiap mahasiswa berbeda satu sama lain. Ada tipe mahasiswa yang terbuka (Ekstrovert) dan ada yang bersifat tertutup (Introvert). Dalam hal ini dosen harus mampu berkomunikasi dengan baik dengan para mahasiswa agar dapat diperoleh solusi dari permasalahan yang ada. Sebagai contoh: Mahasiswa yang hampir tidak pernah masuk perkuliahan, hendaknya di sini ada pemahaman satu sama lain untuk terlebih dahulu masalah utama yang dialaminya sehingga dapat dicarikan dan diberikan solusi yang tepat dan tentunya solusi tersebut tidak melanggar prinsip etika dan moralitas.

Kebiasaan-5 Mahasiswa yang mempunyai karakter berusaha memahami terlebih dahulu, baru dipahami. Pada bagian ini mahasiswa hendaknya dapat juga memahami karakter atau gaya dari setiap dosen dan tidak boleh menyamakan dosen A dengan dosen B serta pengalaman dosen A dengan dosen B. Setiap dosen mempunyai spesialisasi dan fokus masing-masing dan tidak semuanya sama, jadi mahasiswa pun perlu memahami hal ini dan mempunyai pengertian yang besar terhadap dosen-dosennya.

Kebiasaan-6 Mahasiswa yang mampu mewujudkan sinergi. Pada kebiasaan ke 6 ini mahasiswa diharapkan juga mampu mewujudkan sinergi atau dapat berkeja sama dengan baik untuk dapat menghasilkan inovasi atau hal-hal lainnya yang berguna untuk kepentingan komunitas. Mahasiswa harus belajar untuk tidak membawa masalah pribadinya kepada tahap pembelajaran begitu juga dengan dosen. Dalam tahap ini diperlukan penguasaan diri yang baik.[14];[15]

Kebiasaan-7 Mahasiswa yang mempunyai karakter asah gergaji. Pada tahap akhir ini, mahasiswa diharapkan mampu mengembangkan pengetahuannya. Bukan hanya menerima apa yang diberikan dosen pada saat perkuliahan tetapi mahasiswa aktif untuk juga memberikan masukan-masukan dan memberikan informasi yang berharga guna mengembangkan pengetahuan dan karakternya.[12];[13]

\subsection{Tantangan Universitas Dalam Pengembangan Dosen Dan Mahasiswa}

Ini adalah merupakan bagian akhir daripada pembahasan kita. Pada gambar di bawah ini, kita akan memahami apa yang menjadi tantangan utama unviersitas di masa depan mengenai teknologi dan kebiasaan serta karakter.

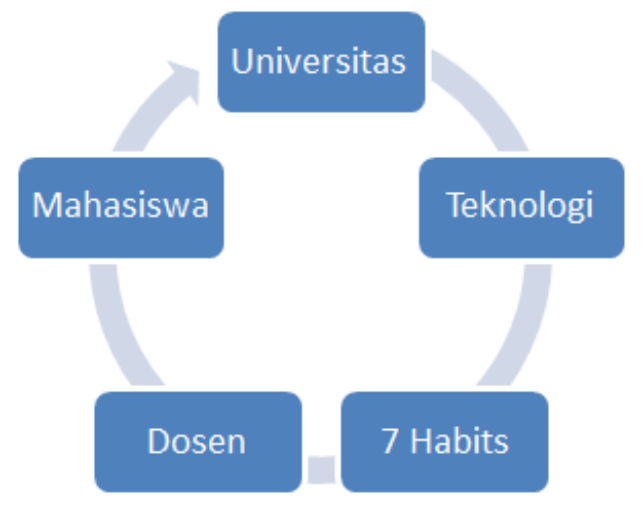

Gambar 8. Tantangan Universitas Dalam Mengembangkan Dosen - Mahasiswa Melalui 7 Habits Dan Hubungannya Dengan Teknologi 
Pada gambar 8, kita dapat melihat bahwa terdapat lingkaran antara Universitas dan beberapa hal penting yang perlu diperhatikan. Hal pertama adalah Universitas harus dapat mengadopsi teknologi yang tepat di dalam pengembangannya sehingga jika hal ini dapat dilakukan, maka universitas dapat meningkatkan kualitas terhadap dosen dan mahasiswa serta proses kerja yang efektif dan efisien. Hal kedua yang merupakan hal yang terpenting adalah Universitas dapat menerapkan kebiasaan-kebiasaan yang sangat dibutuhkan oleh pihak dosen dan mahasiswa. Alasan utama tidak boleh hanya berfokus pada pengembangan teknologi tetapi melupakan pengembangan karakter atau perbaikan kebiasaan adalah merupakan hal yang sangat penting dan hal ini akan dapat menjadi sentral daripada dihasilkannya sumber daya manusia yang sangat kompetitif.[21]

Kebiasaan 1: Proaktif, Universitas tipe proaktif. Universitas tipe ini adalah merupakan universitas yang mempunyai karakter bertanggung jawab tinggi. Dimana Universitas berusaha mengembangkan diri dan mengadopsi teknologi yang canggih untuk dapat meningkatkan kualitas dan memperbaiki proses bisnis yang terdapat di dalam universitas. Lebih jauh lagi, perubahan ini harus dapat diikuti oleh perubahan yang mendasar dan mempunyai etika karena hal ini akan sangat berpengaruh kepada pertumbuhan karakter atau dengan kata lain dapat membentuk budaya dasar dari universitas itu sendiri.

Kebiasaan 2: Merujuk pada tujuan akhir, atau mulailah dengan mengingat-ingat tujuan. Universitas mempunyai tujuan yang jelas, dan tidak terus menerus mengubah visi. Hal ini dimaksudkan jika visi, misi dan tujuan yang telah dibuat bersifat jangka pendek maka hal tersebut akan dapat menjadi permasalahan besar di dalam universitas. Mengapa hal ini bisa terjadi ? karena jika tidak ditetapkan tujuan jangka panjang yang teratur maka akan berikat kekacauan proses di dalam universitas sehingga hal ini dapat berakibat turunnya efektifitas dan efisiensi pada universitas itu sendiri.

Kebiasaan 3: Dahulukan yang utama, Universitas harus mampu untuk menetapkan prioritasnya dan tidak menetapkan terlalu banyak hal-hal yang tidak penting. Yang perlu diperhatikan di sini adalah bahwa universitas harus menyusun prioritas pengembangan teknologi mana yang akan diterapkan tetapi didampingi oleh pengembangan kebiasaan dan ukuran atau indikator apa saja yang perlu diperhatikan di sini.[23]

Kebiasaan 4: Berpikir Menang-Menang. Universitas harus dapat berpikir secara diplomatis, fokus dan sistematis tetapi dinamis. Maksudnya adalah universitas harus mau mengadopsi beberapa budaya dan teknologi yang memang dibutuhkan untuk pengembangan universitas tersebut. Fleksibilitas memang sangat dibutuhkan tetapi tidak boleh menggantikan etika dan integritas daripada moral itu sendiri.[24]

Kebiasaan 5: Berusaha memahami terlebih dahulu, baru dipahami. Universitas pada tahap ini harus dapat belajar untuk memahami para dosen untuk dapat diberikan masukan guna pengembangan inovasi baru di dalam universitas. Pada tahap ini, harus dapat melihat dengan pikiran terbuka karena perkembangan teknologi mempengaruhi banyak hal dan mengubah kebiasaan tertentu yang merupakan dasar dari terbentuknya sebuah prinsip hidup. Hal ini harus dapat dipikirkan dengan baik karena mempengaruhi dihasilkannya sumber daya manusia yang berkualitas tinggi tetapi bermental tidak baik atau berkualitas tinggi tetapi bermental sangat baik.[25]

Kebiasaan 6: Wujudkan Sinergi. Universitas pada tahap ini diharapkan mampu untuk bekerja sama dengan baik, tetapi tidak hanya dengan pihak di luar universitas. Faktor internal juga harus sangat diperhatikan seperti dosen yang perlu dikembangkan dan para mahasiswa yang mempunyai masalah. Universitas tidak hanya berfungsi untuk menghasilkan produk manusia ilmu pengetahuan yang tinggi tetapi mengorbankan kualitas. Ada keseimbangan antara kualitas dan kuantitas. Ini merupakan topik menarik dan tersendiri yang akan dibahas lebih mendalam.[26]

Kebiasaan 7: Asahlah Gergajimu. Universitas pada tahap ini, mampu meningkatkan diri secara berkesinambungan melalui proses belajar terus menerus. Mungkin dengan mengadakan program-program seperti pertukaran pelajar, pertukaran budaya dan joint program untuk S1 dan S2. Di sini, dibutuhkan kejujuran dalam melihat lebih dalam apa yang kurang dan apa yang sudah ada. Apa yang sudah ada dikembangkan dengan sungguh-sungguh menempatkan orang-orang di posisi yang tepat dan apa yang kurang, universitas harus mau mengoreksi dirinya dan berubah ke arah yang lebih baik bukan menutup diri terhadap perkembangan yang baik.[27]. Pertanyaan penting yang harus diajukan adalah:

a. Seberapa penting universitas untuk mengoreksi dirinya ?

b. Apakah pembangunan budaya disiplin sangat penting?

Kedua pertanyaan ini menjadi dasar untuk peningkatkan kualitas di dalam universitas. Walaupun ada faktor-faktor lainnya yang tidak kalah pentingnya tetapi ke dua pertanyaan ini mungkin bisa mewakili prinsip-prinsip yang dikemukakan oleh Stephen R.Covey. Salah satu faktor jatuhnya universitas adalah universitas tidak mau mengoreksi diri atau dengan kata lain jujur pada dirinya. Membandingkan dengan universitas lain baik tingkat nasional maupun di luar negeri memang sangat penting tetapi ada yang jauh lebih penting adalah menciptakan keunikan sendiri, apa yang menjadi faktor menjual di dalam universitas tersebut tanpa mengorbankan kualitas. Dan untuk pertanyaan kedua seperti budaya disiplin, ini juga merupakan faktor yang sangat penting untuk diperhatikan sebab budaya disiplin akan dapat 
mempengaruhi banyak hal seperti keteraturan system dan proses yang terdapat di dalam proses belajar mengajar, administrasi, dan hal-hal yang menyangkut dosen serta mahasiswa.[22]

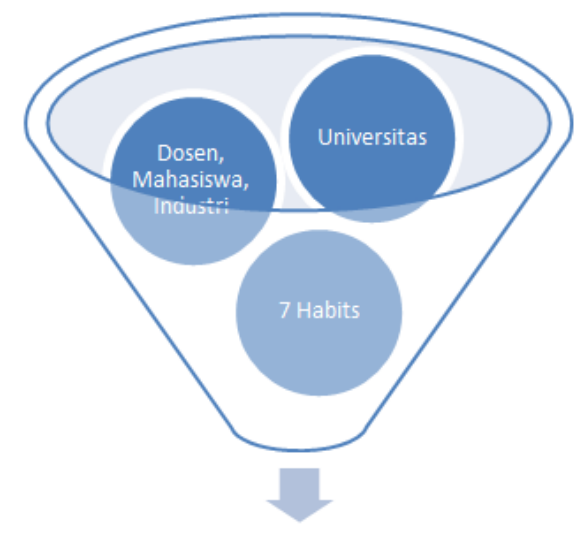

Inovasi, Produk

\section{Gambar 9. Gabungan Yang Menghasilkan Produk Inovasi Berkualitas Tinggi}

Pada gambar 9, kita dapat melihat bahwa peran industri juga akan sangat berpengaruh pada pengembangan universitas dalam menghasilkan sebuah inovasi atau beberapa inovasi yang akan dapat mengubah kehidupan komunitas. Dan satu hal yang tidak boleh dilupakan adalah bahwa 7 kebiasaan tidak boleh dilepaskan dari hal ini karena akan mempunyai pengaruh yang dapat menyebabkan perubahan dalam prinsip dan paradigma yang akan dibentuk. Pembentukan paradigma dalam universitas harus mempunyai karakter 2 arah bukan 1 arah karena ini merupakan hasil penerapan dari 7 kebiasaan yang sangat efektif.

\subsection{Arah Pengembangan Di Abad Globalisasi (E-Habits)}

Sebagai hal terakhir yang akan dibahas di sini adalah, bahwa abad globalisasi adalah abad yang akan sangat mempengaruhi perkembangan mental manusia dan pertumbuhan karakter. Seperti yang sudah dijelaskan sebelumnya bahwa terdapat banyak pengaruh penting yang perlu untuk dipertimbangkan, diperhatikan dan dirombak agar dapat menghasilkan kualitas yang tinggi baik dalam hal dosen, mahasiswa, universitas, faktor budaya dan sebagainya.[28];[29]

Perubahan-perubahan ini perlu diikuti oleh disiplin dan perubahan diri agar siap dalam menghadapi perubahan yang ada dan siap untuk dapat bertumbuh ke arah yang lebih baik seperti kebiasaan ke 7 , yaitu asahlah gergajimu.

Pada gambar 10, berikut ini akan menggambarkannya perubahan yang diperlukan di dalam kerangka $E$ Habits.

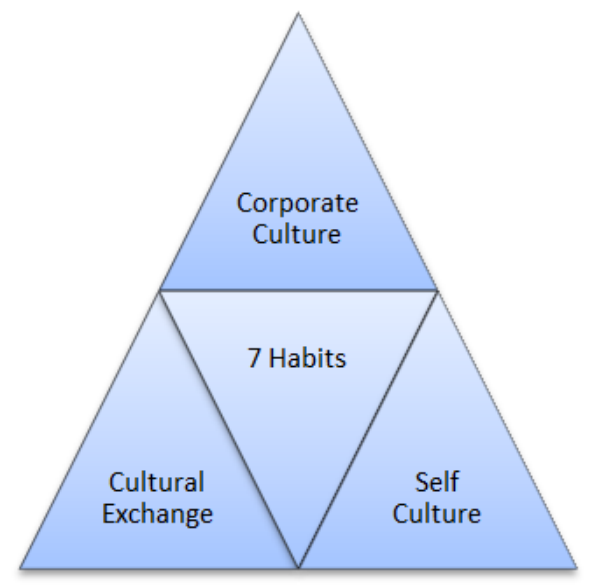

Gambar 10. Perubahan Yang Diperlukan- Kerangka E-Habits 
Tujuh kebiasaan dikelilingi oleh 3 hal penting, yaitu corporate culture-culture exchange dan self culture. Ke tiga hal ini tidak boleh dipisahkan satu sama lain. Mengapa?, karena pada saat memisahkan ketiga hal ini dan hanya berdiri sendiri-sendiri, maka akan dihasilkan perubahan budaya yang tidak stabil. Pertama corporate culture harus ada perubahan di dalam organisasi/perusahaan, dengan cara bijaksana menggunakan teknologi informasi sebagai fasilitas yang tidak dapat dilepaskan sehari-hari daripada kegiatan pekerjaan, tetapi di sini perlu dibentuk yang dinamakan budaya menghargai waktu, sebagai contoh dimana dosen dalam dunia universitas, menyelesaikan pekerjaannya dengan tepat-baik dan benar, di sisi lainnya, mahasiswa harus dapat menjadi lebih konsisten dalam mempelajari apa yang sudah diberikan, dengan ini maka budaya akan dapat terbangun dengan baik dan benar, dan akan terdapat perubahan di dalam lingkungan karena melihat kebiasaan-kebiasaan yang baik, yang terdapat di dalam diri orang tersebut. Culture exchange, perubahan dapat dimulai juga dengan mengadopsi kebudayaan lain ke dalam kebudayaan kita, jika budaya yang berbeda jauh lebih baik, kita harus memiliki kebiasaan untuk mengadopsi hal tersebut ke dalam budaya tersebut, sehingga kita tidak kalah bersaing secara positif. Self culture, merupakan hal-hal yang dibentuk di dalam diri seseorang, bagaimana kita mengembangkan diri sendiri dan bagaimana menghadapi hidup itu. Tetapi hal yang paling krusial adalah apakah/mungkinkan kita melepaskan diri dari teknologi informasi untuk membentuk kebiasaan baik tersebut?, jawabannya tidak!, namun seseorang dapat menggunakannya secara bijaksana, tanpa perlu menghilangkan hal tersebut, itu semua kembali kepada pribadi siapa ia percaya, karena apa yang menjadi teladannya akan merupakan cermin kehidupannya sendiri.

\section{KESIMPULAN}

Kesimpulan dari penelitian ini adalah:

a. Penerapan 7 kebiasaan manusia yang sangat efektif ini sangat mutlak diperlukan di tingkatan dosen dan mahasiswa agar dapat menghasilkan dosen dengan tingkat kualitas tinggi dan mahasiswa yang mempunyai innovation thingking yang tinggi.

b. Perubahan diri mutlak diperlukan dan melatih kebiasaan-kebiasaan yang baik juga mutlak sangat diperlukan guna menghasilkan karakter dosen dan mahasiswa yang mempunyai potensi tinggi di masa depan.

c. Konsistensi dalam melakukan hal ini diperlukan karena jika berhenti pada kebiasaan tertentu atau hanya pada kebiasaan 1 atau lainnya maka tidak akan menghasilkan hasil yang maksimum

d. Kerjasama antara dosen dan mahasiswa sangat diperlukan dan sangat membutuhkan penguasaan diri yang baik.

\section{SARAN}

Pada saat menerapkan ini, dosen diharuskan terlebih dahulu memberikan contoh yang baik, baik dalam perilaku yang etis dan perkataan yang etis. Mahasiswa diberikan pengertian dan pemahaman yang benar tentang hal-hal apa saja yang akan didapatkan mereka di masa depan jika melakukan 7 kebiasaan yang sangat efektif ini. Perlu adanya perubahan dari para dosen terlebih dahulu baru kepada mahasiswa karena dosen merupakan contoh dan teladan.

\section{UCAPAN TERIMA KASIH}

Pertama-tama, terima kasih kepada Rektor; Dekan; Kaprodi yang telah mendukung penelitian ini sehingga dapat dihasilkan dengan sempurna. Kedua, terima kasih kepada para dosen yang telah memberikan masukannya. Ketiga, terima kasih kepada pihak-pihak yang telah banyak membantu sehingga penelitian ini dapat diselesaikan dan memberikan kontribusi positif kepada Universitas, baik kepada dosen dan mahasiswa.

\section{DAFTAR PUSTAKA}

[1] Adams, Julie., 2013, The 7 Habits of Highly Effective Instructional Leaders, Adams Educational Consulting

[2] Armstrong, Thomas., 2002, 7 Kinds Of Smart: Menemukan Dan Meningkatkan Kecerdasan Anda Berdasarkan Teori Multiple Intelligence, PT. Gramedia Pustaka Utama

[3] Charam, Ram., 2007, Know How - 8 Ketrampilan Yang Menjadi Ciri Pemimpin Sukses, PT. Gramedia Pustaka Utama

[4] Chillibreeze, 2014, Modeling the Honeycomb Structure to Present Management Issues, https://www.24point0.com/honeycomb-structure-business-concepts/ 
[5] Cloud, Henry. 2006, Integritas: Keberanian Memenuhi Tuntutan Kenyataan - Cara Enam Kualitas Utama Menentukan Kesuksesan Anda, PT. Gramedia Pustaka Utama

[6] Cooley, Delonia dan Parks, Rochelle., Impact Of Traditional/Social Media Screening Mechanisms On Employers' Perceptions Of Jobs Applicant, The Journal Of Social Media In Society, 5(3), P.151

[7] Covey, S. 1989. The seven habits of highly effective people. New York: Free Press.

[8] David J.Schwartz, 2007, Berpikir Dan Berjiwa Besar (The Magic Of Thinking Big), Binarupa Aksara

[9] Ellen R. Delisio, 2011, Using Covey's 'Seven Habits' To Create Tomorrow's Leaders, Education World

[10] Franklin Covey Education, 2015, Using Stephen R. Covey's The 7 Habits Of Highly Effective People In Education, Franklin Covey Co.

[11] Guskey, T. H., 2013. The case against percentage grades. Educational Leadership, 71(1), 68-72

[12] Iftanti, Erna. 2012, A Survey Of The English Reading Habits Of EFL Students In Indonesia, Teflin Journal, Vol.23, No.2, Teflin Publication Division, English Department, Faculty Of Letters States University Of Malang, Indonesia http://journal.teflin.org/ index.php/journal/ article/view/144

[13] Jayeon Lee dan Raymond J. Pingree, Cues About Cues In Political Comments On Social Media: Effects Of Commenters' Attractiveness And Claims Of Cognitive Effort, The Journal Of Social Media In Society, 5(3), P.92

[14] Jim Collins, 2004, Good To Great (Baik Menjadi Hebat): Mengapa Perusahaan Berhasil Melompat Ke Depan Dan Perusahaan Lain Tidak, Karisma Publishing

[15] Jingbo Meng, Lourdes Martinez dan Amanda Holmstorm, 2017, Reseach On Social Networking Sites And Social Support from 2004 To 2015: A Narrative Review And Directions For Future Research, Cyberpyscology, Behaviour, And Social Networking, Vol.20, No.1.

[16] Johanna Gunnlaugsdottir, Employee Use Of Social Media For Private Affairs During Working Hours, The Journal Of Social Media In Society, 5(3), P.121

[17] John C. Maxwell, 2003, Etika: Yang Perlu Diketahui Setiap Pemimpin, Libri

[18] John C. Maxwell, 2004, Tidak Ada Yang Namanya "Etika Bisnis" (There's No Such Thing As "Business Ethics"): Hanya Ada Satu Aturan Untuk Mengambil Keputusan, Interaksana

[19] John C. Maxwell, 2015, Good Leaders Ask Great Questions, MIC Publishing

[20] John Gottman dan Joan DeClaire, 1998, Kiat-Kiat Membesarkan Anak Yang Memiliki Kecerdasan Emosional, PT. Gramedia Pustaka Utama.

[21] Kingsbury, Kathleen. 2008, The 7 Habits of Highly Effective Schools, Time

[22] Kurniasih, Nuning., 2016, Reading Habits In Digital Era: Indonesian People Do Not Like Reading: Is It True?, World Culture Forum, Bali, Indonesia https://worldcultureforum-bali.org/reading-habitin-digital-era-indonesian-people-do-not-like-reading/

[23] Natascha Zeilel-Bank dan Ute Tat, Social Media And Its Effect On Individual And Social Systems, Management Knowledge And Learning, International Conference 2014, Human Capital Without Borders: Knowledge And Learning For Quality Of Life, 25-27 June'2014

[24] Norman L. Geisler dan Randy Douglas, 2007, Integrity @ Work: Menjaga Integritas Di Dunia Yang Sekuler, Penerbit Andi

[25] Prashnig, Barbara. 2007, The Power of Learning Styles, Kaifa

[26] Seifert, Kelvin. 2010, Manajemen Pembelajaran \& Instruksi Pendidikan (Manajemen Mutu Psikologi Pendidikan Para Pendidik), IRCiSoD

[27] Sheldon, Pavica., Self-Monitoring, Covert, Narcissim, And Sex As Predictors Of Self-Presentational Activities On Facebook, The Journal Of Social Media In Society, 5(3), P.70

[28] Snapchart Asia , 2017, Indonesia Social's Media Behaviour, https://snapcart.asia/indonesias-socialmedia-behaviour/

[29] Techinasia, 2015, Here are some rare insights into how Indonesians consume apps, http://tech01.us/asia/here-are-some-rare-insights-into-how-indonesians-consume-apps-2015-08-24

[30] Wormeli, R., 2013, Take time for yourself - and for learning. Educational Leadership, 70(9), 14-19.

[31] Wormeli, R., 2014, Teacher coach: Teachers' intellectual lives. AMLE Magazine, 1(9), 39-40.

[32] Wormeli, Rick., 2015, The Seven Habits of Highly Affective Teachers, Vol.73, No.2, 10-15, ASCD, Educational Leadership 